\title{
Antioxidant Protection of Photosynthesis in Two Cashew Progenies Under Salt Stress
}

\author{
Anselmo F. da Silva ${ }^{1}$, Valéria F. de O. Sousa ${ }^{2}$, Gisele L. dos Santos², Eugênio S. Araújo Júnior ${ }^{3}$, \\ Sérgio L. F. da Silva ${ }^{3}$, Cristiane E. C. de Macedo ${ }^{4}$, Alberto S. de Melo ${ }^{5}$ \& Josemir M. Maia ${ }^{6}$ \\ ${ }^{1}$ Academic Unit of Agronomy, Federal University of Paraiba, Areia, PB, Brazil \\ ${ }^{2}$ Academic Unit of Tropical Horticulture, Federal University of Campina Grande, Pombal, PB, Brazil \\ ${ }^{3}$ Academic Unit of Production Vegetable, Rural Federal University of Pernambuco, Serra Talhada, PE, Brazil \\ ${ }^{4}$ Academic Unit of Fitotecnia, Rural Federal University of the Semi-Arid, Mossoró, RN, Brazil \\ ${ }^{5}$ Academic Unit of Agrarian Sciences, State University of Paraiba, Campina Grande, PB, Brazil \\ ${ }^{6}$ State University of Paraíba, Center for Human and Agrarian Sciences, Catolé do Rocha, Paraíba, Brazil \\ Correspondence: Josemir M. Maia, State University of Paraíba, Center for Human and Agrarian Sciences, Catolé \\ do Rocha, Paraíba, Brazil. E-mail: jmouram@gmail.com
}

Received: June 28, $2018 \quad$ Accepted: August 7, $2018 \quad$ Online Published: September 15, 2018

doi:10.5539/jas.v10n10p388 URL: https://doi.org/10.5539/jas.v10n10p388

\begin{abstract}
The present work evaluated the indicators of photosynthetic efficiency and antioxidative protection in cashew tree seedlings subjected to salinity stress. The study was conducted with seedlings of two advanced dwarf cashew clones (CCP09 and CCP76) subjected to salt stress with increasing doses of $\mathrm{NaCl}(0$, control; 25; 50; 75; $100 \mathrm{mM})$ in the nutrient solution for 30 days under greenhouse conditions. The variables of gas exchange, $\mathrm{CO}_{2}$ assimilation $\left(\mathrm{P}_{N}\right)$, stomatal conductance $\left(\mathrm{g}_{\mathrm{S}}\right)$, transpiration $(\mathrm{E})$, intercellular $\mathrm{CO}_{2}$ concentration $\left(\mathrm{C}_{I}\right)$, photochemical activity, potential quantum efficiency $(\mathrm{Fv} / \mathrm{Fm})$, effective quantum efficiency $(\Delta \mathrm{F} / \mathrm{Fm}$ ') of photosystem II (PSII), photochemical quenching (qP), non-photochemical quenching (NPQ) electron transport rate (ETR) as well as the indicators of damage and oxidative protection were measured. Under these conditions, there was an intense accumulation $\mathrm{Na}^{+}$associated with a reduction in the $\mathrm{K}^{+} / \mathrm{Na}^{+}$ratio in the leaves of both clones in response to salt, with higher values for this ratio in clone CCP09 than in CCP76 the highest concentration of $\mathrm{NaCl}(100 \mathrm{mM})$. Salinity reduced $\mathrm{P}_{\mathrm{N}}, \mathrm{g}_{\mathrm{S}}$ and $E$ in the two clones evaluated, with lower reductions in CCP09 than in CCP76 at the highest salt dose. Instantaneous carboxylation $\left(\mathrm{P}_{N} / \mathrm{C}_{I}\right)$ and water use $\left(\mathrm{P}_{N} / \mathrm{E}\right)$ efficiencies were strongly restricted by salinity but were less affected in CCP09 than in CCP76. Salinity stress also increased hydrogen peroxide $\left(\mathrm{H}_{2} \mathrm{O}_{2}\right)$ levels in CCP09, whereas lipid peroxidation decreased in both progenies. The clones presented specific antioxidant responses due to greater enzymatic and non-enzymatic activity in CCP76, in addition to the activity of phenol peroxidase (POX) in CCP09.
\end{abstract}

Keywords: Anacardium occidentale, oxidative stress, photosynthesis, salinity

\section{Introduction}

Excess of salt in the soil solution causes metabolic disturbances in plants due to the osmotic and ionic effects of salinity, leading to reduced crop growth and productivity (Khan \& Panda, 2008; Lima, Nobre, Gheyi, Soares, \& Silva, 2014). The osmotic effect is immediate due to the difference in osmotic potential between the external and internal environments of the cell, whereas the ionic effect occurs later when the concentration of $\mathrm{Na}^{+}$and/or $\mathrm{Cl}^{-}$ reaches toxic levels in the cytosol (Shavrukov, 2013). At the time of exposure to salinity, these osmotic/ionic effects act simultaneously, affecting essential metabolic processes such as nutritional balance, water relations and photosynthesis (Shaheen, Naseer, Ashraf, \& Akram, 2013; Chen, Hawighorst, Sun, \& Polle, 2014).

Ionic toxicity caused by salinity stress results from increased $\mathrm{Na}^{+} / \mathrm{K}^{+}, \mathrm{Na}^{+} / \mathrm{Ca}^{+2}, \mathrm{Na}^{+} / \mathrm{Mg}^{+2}$ and $\mathrm{Cl}^{-} / \mathrm{NO}_{3}{ }^{-}$ratios in plant tissue, causing cellular disorders related to the physiological function of these essential nutrients (Abbaspour, Kaiser, \& Tyeman, 2014; Bessa, Lacerda, Amorim, Bezerra, \& Lima 2016). $\mathrm{K}^{+}$is a macronutrient that participates in several cellular functions, acting on osmotic potential (osmosolute function) and the functioning of metabolic pathways due to its role as an enzymatic cofactor (Wang \& Wu, 2013). Thus, the 
$\mathrm{K}^{+} / \mathrm{Na}^{+}$ratio in plant tissue is considered a physiological marker of $\mathrm{K}^{+}$selectivity and the resulting resistance to salinity stress in some species and/or agricultural crops (Rodrigues et al., 2013; Bessa et al., 2016).

Salinity affects the absorption process by restricting $\mathrm{K}^{+}$accumulation in different parts of plants, a response that has been previously shown to occur in cashew trees (Ferreira-Silva, Voigt, Viégas, Paiva, \& Silveira, 2009). A lower $\mathrm{K}^{+} / \mathrm{Na}^{+}$ratio in response to salt is associated with other metabolic disturbances, such as photosynthetic limitation and photooxidative damage (Rodrigues et al., 2013). Photosynthetic limitation is among the first physiological responses exhibited by plants subjected to salinity (Shaheen et al., 2013). A reduction of this process may be associated with both stomatal limitation (Hussain, Luro, Costantino, Ollitrault, \& Morillon, 2012) and non-stomatal factors (Rodrigues et al., 2013).

In addition to stomatal limitation, salinity can affect the structural components of photosystem II (PSII) and can compromise photochemical efficiency, limiting the capture and use of light energy (Silveira \& Carvalho 2016). Damage to PSII can occur due to the photooxidation of structures such as pigments (chlorophylls) and proteins, particularly the D1 protein, caused by the generation of excess reactive oxygen species (ROS) at PSII (Goh, Ko, Koh, Kim, \& Bae, 2012). This damage affects PSII repair systems and can lead to chronic photoinhibition, causing non-stomatal photosynthetic limitation (Hussain et al., 2012). In chloroplasts, in addition to the photochemical disturbances caused by salinity, the limitation of carbon reduction in the Calvin cycle can lead to an increase in the NADPH/NADP ${ }^{+}$ratio, stimulating the generation of ROS due to oxygen $\left(\mathrm{O}_{2}\right)$ photoreduction at photosystem I (Goh et al., 2012).

This imbalance of the photosynthetic process causes changes in the redox state that increase the content of ROS and oxidative damage (Mittler, 2002). For protection, plant cells evolved a complex system that involves enzymatic mechanisms consisting of enzymes such as superoxide dismutase (SOD), ascorbate peroxidase (APX) and phenol peroxidase (POX) and non-enzymatic mechanisms consisting of chemical components such as ascorbate (ASC) and glutathione (GSH), which act together in cellular protection (Dinakar, Djilianov, \& Bartels, 2012; Šimková, Fialová, Vaculíková \& Luxová, 2016). SOD is present in different compartments of the cell and dismutates the superoxide radical $\left(\mathrm{O}_{2}{ }^{\circ}\right)$ to hydrogen peroxide $\left(\mathrm{H}_{2} \mathrm{O}_{2}\right)$ and water (Bhattacharjee, 2010). Peroxidases (APX and POX) remove excess generated $\mathrm{H}_{2} \mathrm{O}_{2}$ using specific electron donors (Maia et al., 2012).

Cashew (Anacardium occidentale L.) trees are economically important in Brazil. Cashew nut production reached $228,796 \mathrm{t}$ in 2016 (IBGE, 2016). This species is cultivated under dry conditions in the Brazilian semiarid region under adverse environmental conditions. Salinity affects cashew growth, but the species is moderately salt tolerant; some clones can exclude $\mathrm{Na}^{+}$, which is a favorable attribute for salt resistance (Ferreira-Silva et al., 2010). Genetic variability in relation to characters involved in salt resistance, such as ionic partitioning (Ponte et al., 2011) and oxidative protection (Ferreira-Silva et al., 2011), also exists.

Despite these few reports in the literature, metabolic disturbances related to photosynthetic limitation in cashew plants cultivated under salinity conditions are not characterized. In the present study, the characterization of both photosynthetic damage and metabolic disorders related to the generation of oxidative damage was carried out in two cashew tree progenies subjected to salinity stress. The effects of salinity on stomatal modulation and photochemical activity associated with the $\mathrm{K}^{+} / \mathrm{Na}^{+}$ratio in leaf tissue are also discussed.

\section{Material and Methods}

\subsection{Plant Material and Application of Treatments}

Seeds (cashew nuts) of advanced dwarf cashew (Anacardium occidentale L.) trees were obtained from a commercial nursery in Pacajus city, Ceará, Brazil. The experiment was carried from June to October 2015 out at the Unidade Acadêmica de Serra Talhada of the Universidade Federal Rural de Pernambuco. Nuts were subjected to superficial disinfestation with $5 \%(\mathrm{v} / \mathrm{v})$ sodium hypochlorite and sown into $4.0 \mathrm{~L}$ pots containing a mixture of vermiculite and sand as a substrate at a ratio of 1:1 (v/v). During the germination and initial growth stages, substrate moisture was maintained near field capacity by frequent irrigation with distilled water for 20 days. Afterward, seedlings (stage of four expanded leaves) received nutrient solution described by Hoagland and Arnon (1950).

Thirty days after planting, seedlings were subjected to different salinity treatments in increasing concentrations of $\mathrm{NaCl}(0$, control; 25; 50; 75; and $100 \mathrm{mM}$ ) dissolved in diluted nutrient solution (one-quarter strength). Treatment solutions were applied every three days for 30 days, and the photosynthetic parameters were measured at the end of the experiment. Seedlings were then collected, and leaves and stems were separated to determine their fresh mass. Part of the leaves was frozen in liquid nitrogen and stored at $-80{ }^{\circ} \mathrm{C}$ to later analyze the 
indicators of oxidative damage, non-enzymatic antioxidants and enzymatic activity and measure the $\mathrm{Na}^{+}$and $\mathrm{K}^{+}$ contents.

The experiment was carried out in a completely randomized design in a $2 \times 5$ factorial arrangement: two cashew clones (CCP76 and CCP09) and five doses of $\mathrm{NaCl}(0$, control; 25; 50; 75; and $100 \mathrm{mM})$. There were three replicates per treatment for a total of 30 plots, with each one represented by one pot containing one seedling. Data were subjected to the $\mathrm{F}$ test at $0.05 \%$ significance, and means were compared by the Tukey test at the same probability level. For the analysis, the ASSISTAT software (Statistical Assistance) was used 7.7 beta, copy updated on 10/4/2015 (Silva \& Azevedo, 2016).

\subsection{Fresh Mass Content, $\mathrm{Na}^{+}$and $\mathrm{K}^{+}$Contents and $\mathrm{K}^{+} / \mathrm{Na}^{+}$}

The fresh mass of the above ground portion was obtained by measuring fresh leaf and stem tissue using a semi-analytical electronic balance. The extraction for the measurements of $\mathrm{Na}^{+}$and $\mathrm{K}^{+}$content from leaf tissues was performed using $50 \mathrm{mg}$ of vegetable tissue and $10 \mathrm{~mL}$ of deionized water in a $100 \%$ water bath for 1 hour in closed thread tubes. The clear extract was obtained by filtration with cotton, and the $\mathrm{Na}^{+}$and $\mathrm{K}^{+}$contents were measured by flame photometry readings (Malavolta, Vitti, \& Oliveira, 1989).

\subsection{Gaseous Exchange Analysis and Chlorophyll Fluorescence}

The rate of $\mathrm{CO}_{2}$ assimilation $\left(\mathrm{P}_{N}\right)$, transpiration $(E)$ and stomatal conductance $\left(\mathrm{g}_{\mathrm{S}}\right)$ were measured with a portable photosynthesis system (LI-6400XT, LI-COR, USA) with saturating irradiance $\left(1000 \mu \mathrm{mol}\right.$ photons $\left.\mathrm{m}^{-2} \mathrm{~s}^{-1}\right)$ provided by an external halogen lamp to saturate PSII without damage. From these data, water use efficiency, by the $\mathrm{P}_{N} / E$ ratio (Souza, Soares, \& Regina, 2001), and instantaneous carboxylation efficiency, by the $\mathrm{P}_{N} / \mathrm{C}_{I}$ ratio (Ribeiro, Machado, Santos, \& Oliveira, 2009), were calculated. Fluorescence measurements were subsequently performed on mature, fully expanded leaves using the saturation pulse method (Van Kooten \& Snel, 1990; Schreiber, Bilger, \& Neubauer et al., 1994) with a fluorometer coupled to a portable photosynthesis system (LI-6400XT, LI-COR).

From the fluorescence data, the maximum quantum efficiency of PSII based on the Fv/Fm ratio and the following parameters were calculated: PSII quantum efficiency $\left[\Delta \mathrm{F} / \mathrm{F}^{\prime} \mathrm{m}=\left(\mathrm{F}^{\prime} \mathrm{m}-\mathrm{Fs}\right) / \mathrm{F}\right.$ 'm $]$; excitation energy capture efficiency or antenna efficiency $\left[\mathrm{Fv}^{\prime} / \mathrm{Fm}^{\prime}=\left(\mathrm{F}^{\prime} \mathrm{m}-\mathrm{F}^{\prime} \mathrm{o}\right) / \mathrm{F}^{\prime} \mathrm{m}\right]$; apparent rate of electron transport $(\mathrm{ETR}=$ $\Delta \mathrm{F}^{\prime}-\mathrm{F}$ 'm $\times$ photosynthetic photon flux density $\left.\times 0.5 \times 0.84\right)$; non-photochemical quenching $[\mathrm{NPQ}=(\mathrm{Fm}-$ F'm)/F'm]; and photochemical quenching (qP) (Rohácek, 2002). In addition, the ETR/ $\mathrm{P}_{N}$ ratio was calculated to estimate excess electrons in the chloroplastic electron transport chain used in other processes not related to the rate of $\mathrm{P}_{\mathrm{N}}$ (Ribeiro, Santos, Machado, \& Oliveira, 2008).

\subsection{Indicators of Oxidative Damage, Non-enzymatic and Enzymatic Antioxidants}

The $\mathrm{H}_{2} \mathrm{O}_{2}$ content was determined by the method described by Cheeseman et al. (2006). Leaf samples $(0.2 \mathrm{~g}$ of fresh tissue) were macerated in a liquid $\mathrm{N}_{2}$ mortar, followed by extraction in $50 \mathrm{mM}$ potassium phosphate buffer $\mathrm{pH} 6.0$ containing $1 \mathrm{mM} \mathrm{KCN}$. The extract was centrifuged at $12.000 \times \mathrm{g}$ for $30 \mathrm{~min}$ the $4^{\circ} \mathrm{C}$ and aliquots $(200$ $\mu$ l) of the supernatant were transferred to test tubes containing $900 \mu \mathrm{L}$ of in reaction medium, $0,25 \mathrm{mM} \mathrm{FeSO}_{4}$, $0.25 \mathrm{mM}\left(\mathrm{NH}_{4}\right)_{2} \mathrm{SO}_{4} ; 0.25 \mathrm{mM} \mathrm{H}_{2} \mathrm{SO}_{4}, 124 \mu \mathrm{M}$ xylenol orange and $99 \mathrm{mM}$ sorbitol. The mixture was incubated per $30 \mathrm{~min}$ at $25{ }^{\circ} \mathrm{C}$ and then absorbance readings were carried out at $560 \mathrm{~nm}$. The contents ${ }^{\circ} \mathrm{H}_{2} \mathrm{O}_{2}$ were obtained from standard curve and the results expressed in $\mu \mathrm{mol} \mathrm{H}_{2} \mathrm{O}_{2} \mathrm{~g}^{-1} \mathrm{MF}$.

For the thiobarbituric acid (TBARS), ascorbate (ASC) and glutathione (GSH) reactive substance measurements reduced, leaf samples $(0.1 \mathrm{~g})$ were macerated in a mortar in the presence of liquid $\mathrm{N}_{2}$, followed by extraction in solution of TCA $(5 \%)$ and centrifugation at $10,000 \times g$ per $30 \mathrm{~min}$ at $4{ }^{\circ} \mathrm{C}$. Lipid peroxidation was estimated by the thiobarbituric acid reactive substance content (TBARS) according to Heath and Packer (1968). For the reaction, aliquots $(0.5 \mathrm{~mL})$ of the supernatant were added to $2.0 \mathrm{~mL}$ of $20 \%$ TCA solution and $0.5 \%(\mathrm{~m} / \mathrm{v})$ TBA and heated in a $95{ }^{\circ} \mathrm{C}$ water bath in sealed tubes For 1 hour. After the reaction was stopped in an ice bath, readings were carried out at 532 and $660 \mathrm{~nm}$ and after subtraction of the readings, the TBARS content was estimated using the $155 \mathrm{mM}^{-1} \mathrm{~cm}^{-1}$ molar extinction coefficient.

The ASC content was determined according to Kampfenkel et al. (1995). Aliquots ( $0,1 \mathrm{~mL})$ of the supernatant were added to the reaction medium with $0.3 \mathrm{~mL}$ of $200 \mathrm{mM}$ potassium phosphate buffer, $\mathrm{pH} 7.4 ; 0.1 \mathrm{~mL}$ of distilled water; $0.5 \mathrm{~mL}$ of $1 \% \mathrm{TCA} ; 0.4 \mathrm{~mL}$ of $42 \% \mathrm{H}_{3} \mathrm{PO}_{4} ; 0,4 \mathrm{~mL}$ of $4 \%$ bipyridyl; $0.2 \mathrm{~mL}$ of $\mathrm{FeCl}_{3}$. The tubes were brought to the water bath at $42{ }^{\circ} \mathrm{C}$ per $30 \mathrm{~min}$ and after readings were carried out at $525 \mathrm{~nm}$. The content of GSH was determined according to Griffth (1980). Aliquots $(0.2 \mathrm{~mL})$ of the supernatant were added to the reaction medium containing $2.6 \mathrm{~mL}$ of $150 \mathrm{mM}$ sodium phosphate buffer $\mathrm{pH} 7.4 ; 1 \mathrm{ml}$ of $100 \mathrm{mM}$ sodium phosphate buffer $\mathrm{pH} 6.8$ and $0.2 \mathrm{ml}$ of DTNB (5,5 'dithiobis-nitrobenzoic acid) $30 \mathrm{mM}$ in $100 \mathrm{mM}$ phosphate 
buffer, $\mathrm{pH}$ 7.0. The tubes were kept in a water bath at $30^{\circ} \mathrm{C}$ for $10 \mathrm{~min}$ and then readings were carried out at 412 $\mathrm{nm}$. The contents of ACS and GSH were estimated based on standard curve and expressed in $\mu \mathrm{mol} \mathrm{g}^{-1} \mathrm{MF}$.

Protein extraction was performed as described by Zimmermann et al. (2006). The activity of the enzyme superoxide dismutase (SOD; EC: 1.15.1.1) was determined according to the methodology described by Giannopolitis and Ries (1977). $0.1 \mathrm{ml}$ aliquots of the protein extract were transferred to light-protected test, tubes containing $50 \mathrm{mM}$ potassium phosphate buffer, $\mathrm{pH}$ 7.8; Containing $0.1 \mathrm{mM}$ EDTA; $13 \mathrm{mM}$ L-methionine and $750 \mu \mathrm{M}$ nitroblue tetrazolium (NBT). The reaction was initiated by the addition of $2 \mathrm{mM}$ riboflavin and rapid transfer of the tubes, without light protection, to a 30-watt lamp-illuminated chamber ( $30 \mu \mathrm{mol}$ of photons $\left.\mathrm{m}^{-2} \mathrm{~s}^{-1}\right)$ for 7 minutes. The reaction was interrupted by the shutdown of light and readings were carried out at $560 \mathrm{~nm}$. The activity of the enzyme was estimated on the basis of inhibition of NBT and one unit of activity was considered as the amount of enzyme required to inhibit $50 \%$ of its reduction by Beauchamp and Fridovich (1971) and expressed in $\mathrm{UA} \mathrm{g}^{-1} \mathrm{MF} \mathrm{min}^{-1}$.

The activity of ascorbate peroxidase (APX; EC: 1.11.1.1) was determined according to the method described by Nakano and Asada (1981). Aliquots of $0.1 \mathrm{~mL}$ of protein extract were added to the reaction medium composed of $2.7 \mathrm{~mL}$ of $50 \mathrm{mM}$ potassium phosphate buffer $\mathrm{pH} 6.0$ containing $0.5 \mathrm{mM}$ ascorbic acid. The reaction was started by adding $0.2 \mathrm{~mL} \mathrm{H}_{2} \mathrm{O}_{2} 30 \mathrm{mM}$ and accompanied by the decline in absorbance at $290 \mathrm{~nm}$ in a spectrophotometer for 120 seconds, with readings at intervals of $30 \mathrm{sec}$. APX activity was estimated using the molar extinction coefficient of $2.8 \mathrm{mM}^{-1} \mathrm{~cm}^{-1}$ for ascorbate at $290 \mathrm{~nm}$ and expressed as $\mu \mathrm{mol} \mathrm{ASC} \mathrm{g} \mathrm{gF} \mathrm{min}^{-1}$.

The activity of phenol peroxidase (POX; EC 1.11.1.7) was determined according to the reaction principle of the method described by Kar and Mishra (1976). $100 \mu \mathrm{L}$ aliquots of the protein extract were transferred to assay tubes, then added $4.9 \mathrm{~mL}$ of $25 \mathrm{mM}$ potassium phosphate buffer, $\mathrm{pH} 6.8$; Containing $20 \mathrm{mM}$ of pyrogallic acid and $20 \mathrm{mM}$ of $\mathrm{H}_{2} \mathrm{O}_{2}$. The mixture was incubated at room temperature $\left(25^{\circ} \mathrm{C}\right)$ for $1 \mathrm{~min}$ and the reaction Interrupted by the addition of $0.5 \mathrm{~mL}$ of $0.5 \%(\mathrm{v} / \mathrm{v}) \mathrm{H}_{2} \mathrm{SO}_{4}$. Absorbance readings were taken at $40 \mathrm{~nm}$. The POX activity was expressed in nmol purpurogalin $\mathrm{g}^{-1} \mathrm{MS} \mathrm{min}^{-1}$.

\section{Results and Discussion}

\subsection{Growth and Partition of Ions in Cashew Tree Seedlings Subjected to Salinity Stress}

For all parameters evaluated, the clones presented similar responses, with the exception of $\mathrm{K}^{+}$, in which CCP76 maintained a stable $\mathrm{K}^{+}$content but CCP09 tended to increase proportionally with increasing in salinity. From the $50 \mathrm{mM} \mathrm{NaCl}$ dose there was a tendency for fresh weight of shoot to decrease in response to increased salinity (Figure 1A). Torres et al. (2014) suggested that the absolute and relative growth rates of height, stem diameter, leaf number, leaf area and root length as well as fresh phytomass of cashew trees are negatively influenced by the salinity of irrigation water. These authors affirmed that salinity stress decreases plant growth due to the energy consumption required for synthesis of osmotically active organic compounds, which are associated with osmotic adjustment processes and maintenance of water relations in plants. 


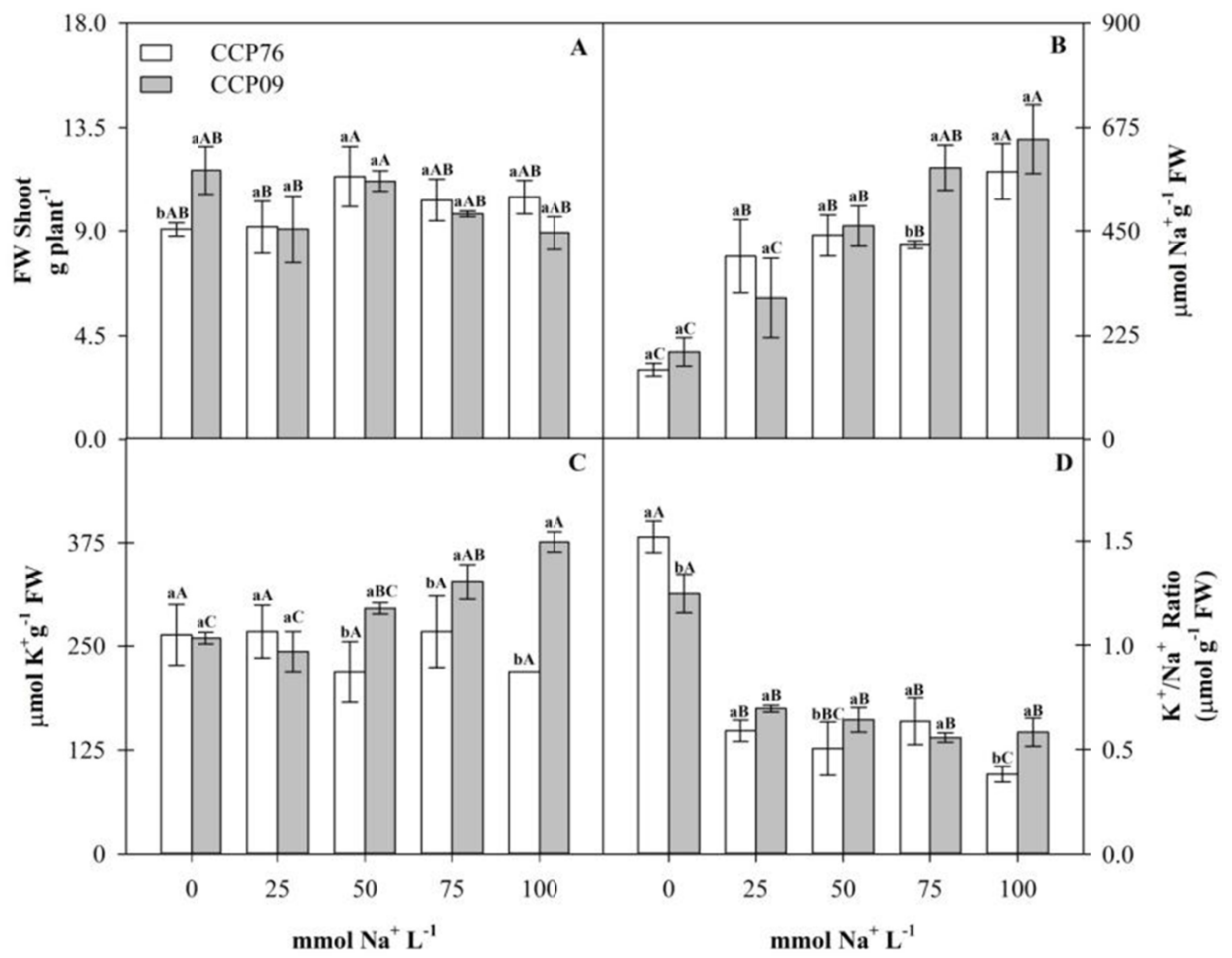

Figure 1. Fresh weight of leaves (A) as well as the $\mathrm{Na}^{+}$content (B), $\mathrm{K}^{+}$content $(\mathrm{C})$ and $\mathrm{K}^{+} / \mathrm{Na}^{+}$(D) in the leaves of early dwarf cashew clones (CCP76 and CCP09) cultivated under control conditions with distilled water and treated with $0 ; 25 ; 50 ; 75$ and $100 \mathrm{mM} \mathrm{NaCl}$ for 30 days. The letters on the bars indicate significant differences according to the Tukey test $(\mathrm{p} \leq 0.05)$. Lowercase letters are associated with the clones; and uppercase letters with doses salinas

The increase in $\mathrm{NaCl}$ in nutrient solution resulted in proportional accumulations of $\mathrm{Na}^{+}$(Figure 1B) of $66.66 \%$ and $67.11 \%$ in clones CCP76 and CCP09, respectively, at $100 \mathrm{mM} \mathrm{NaCl}$, compared with those of the controls. These results were similar to those of Freitas, Marques, Bezerra, Prisco \& Gomes-Filho (2013), who reported an increase in $\mathrm{Na}^{+}$content in the leaves of cashew tree seedlings subjected to salinity stress. On the other hand, the $\mathrm{K}^{+}$content in the leaves increased only in clone CCP09 starting at $50 \mathrm{mM}$ in response to salinity stress (Figure 1C), which may have been caused by the increment of $\mathrm{Na}^{+}$, indicating the occurrence of ionic toxicity associated with a possible nutritional imbalance (Ferreira-Silva, Silveira, Voigt, Soares, \& Viégas, 2008). Marques, Freitas, Bezerra, Prisco, and Gomes-Filho (2011) studied the effects of salinity on cashew seedlings and reported that the $\mathrm{K}^{+}$contents are not altered during the growth stages corresponding to germination and seedling emergence but decrease at the onset of established seedling development, suggesting that the negative effects of excess $\mathrm{Na}^{+}$on absorption and content of $\mathrm{K}^{+}$under saline conditions depend on the growth stage and duration of stress.

In the present study, both clones subjected to the $\mathrm{NaCl}$ treatments $(25,50,75$ and $100 \mathrm{mM})$ presented a $65 \%$ reduction in the $\mathrm{K}^{+} / \mathrm{Na}^{+}$ratio in the aerial portions of the plants (Figure 1D). When these values are lower than 1, ionic toxicity due to the excessive accumulation of $\mathrm{Na}^{+}$in relation to $\mathrm{K}^{+}$is evident (Rodrigues et al., 2013).

\subsection{Photosynthetic Changes Induced by Salinity in Cashew Tree Seedlings}

In the analyzed variables of photosynthetic metabolism, a significant difference was observed between treatments, in which clones displayed similar behavior among themselves. This behavior differed only with respect to water use efficiency $\left(\mathrm{P}_{N} / E\right)$ and qP. Salinity stress dramatically affected $\mathrm{P}_{N}$ (Figure 2A). In the CCP76 clone, $\mathrm{P}_{N}$ decreased by $89.25 \%$ in response to the dose of $100 \mathrm{mM}$ and in CCP09 by $79.51 \%$ in response to the dose of $75 \mathrm{mM}$ compared to control. In cowpea plants, salinity stress promotes a lower rate of $\mathrm{P}_{N}$, which is caused by a reduction in $\mathrm{g}_{\mathrm{s}}$ (Souza, Machado, Silveira, \& Ribeiro, 2011). This effect was also observed in cashew seedlings under salinity stress. 
There was also a significant effect on intercellular $\mathrm{CO}_{2}$ concentration $\left(\mathrm{C}_{\mathrm{I}}\right)$ due to salinity (Figure 2B). There was an increase in $\mathrm{C}_{I}$ in the CCP76 clone of $45.26 \%$ from $100 \mathrm{mM} \mathrm{NaCl}$ but only $7.14 \%$ in CCP09 at the same concentration, when compared to control. The results are in agreement with those reported in other studies (Warren, 2008; Sousa et al., 2012) in several plant species, such as Cocos nucifera, Swietenia macrophylla, Zea mays and Arachis hypogaea subjected to salinity stress and/or different water regimes. As reported in these studies, the increase in $\mathrm{C}_{I}$ may be caused by the direct interference of salinity stress in absorption of water and nutrients; therefore, the amount of water available influences stomatal opening and closure. High concentrations of $\mathrm{Na}^{+}$reduce the turgidity potential of foliar tissues, interfering in the absorption of water. At the same time, stomatal closure and reduction in $\mathrm{C}_{I}$ occur. The reduction in $\mathrm{g}_{\mathrm{S}}$ shown in Figure $2 \mathrm{C}$ likely impaired the stability of gas exchange, reducing the $\mathrm{P}_{\mathrm{N}}$ rate of cashew clones and becoming correlated with the lower influx of $\mathrm{CO}_{2}$ in the sub-stomatal cavity for photosynthesis (Romero-Aranda et al., 1998; Chaves, Flexas, \& Pinheiro, 2009).

In cashew seedlings subjected to salinity stress, drastic reductions in the instantaneous carboxylation efficiency $\left(\mathrm{P}_{N} / \mathrm{C}_{I}\right)$ of approximately $92.85 \%$ for CCP76 and 67\% for CCP09 were observed compared with those of plants in the absence of $\mathrm{NaCl}$ (Figure 2D). The $\mathrm{P}_{N} / \mathrm{C}_{I}$ ratio decreased with increasing $\mathrm{NaCl}$ content in leaf tissue. This decrease can be explained in part by the toxic effect of increasing concentrations of $\mathrm{Na}^{+}$and $\mathrm{Cl}^{-}$in leaves, as reported in other species such as cowpea (Souza et al., 2011) and soybean (Shi, Meng-Zhaolai, Wang, Xu, \& Xu, 2015). It is probable that the reduction in the $\mathrm{P}_{N} / \mathrm{C}_{I}$ ratio is associated with a decrease in $\mathrm{P}_{N}$ (Figure $2 \mathrm{~A}$ ) and therefore lower availability of $\mathrm{CO}_{2}$ as a substrate for photosynthesis.

Increased $\mathrm{NaCl}$ concentration significantly reduced the $\mathrm{g}_{\mathrm{S}}$ of clones CCP76 (60\%) and CCP09 (45.45\%) subjected to $100 \mathrm{mM}$ salinity concentrations (Figure 2D). Among the clones, a significant difference was observed in response to doses of 75 and $100 \mathrm{mM}$, with the $\mathrm{g}_{\mathrm{S}}$ of CCP76 overlapping with that of CCP09 at 75 $\mathrm{mM}$ and the $\mathrm{g}_{\mathrm{S}}$ of CCP09 with that CCP76 at $100 \mathrm{mM} \mathrm{NaCl}$. 


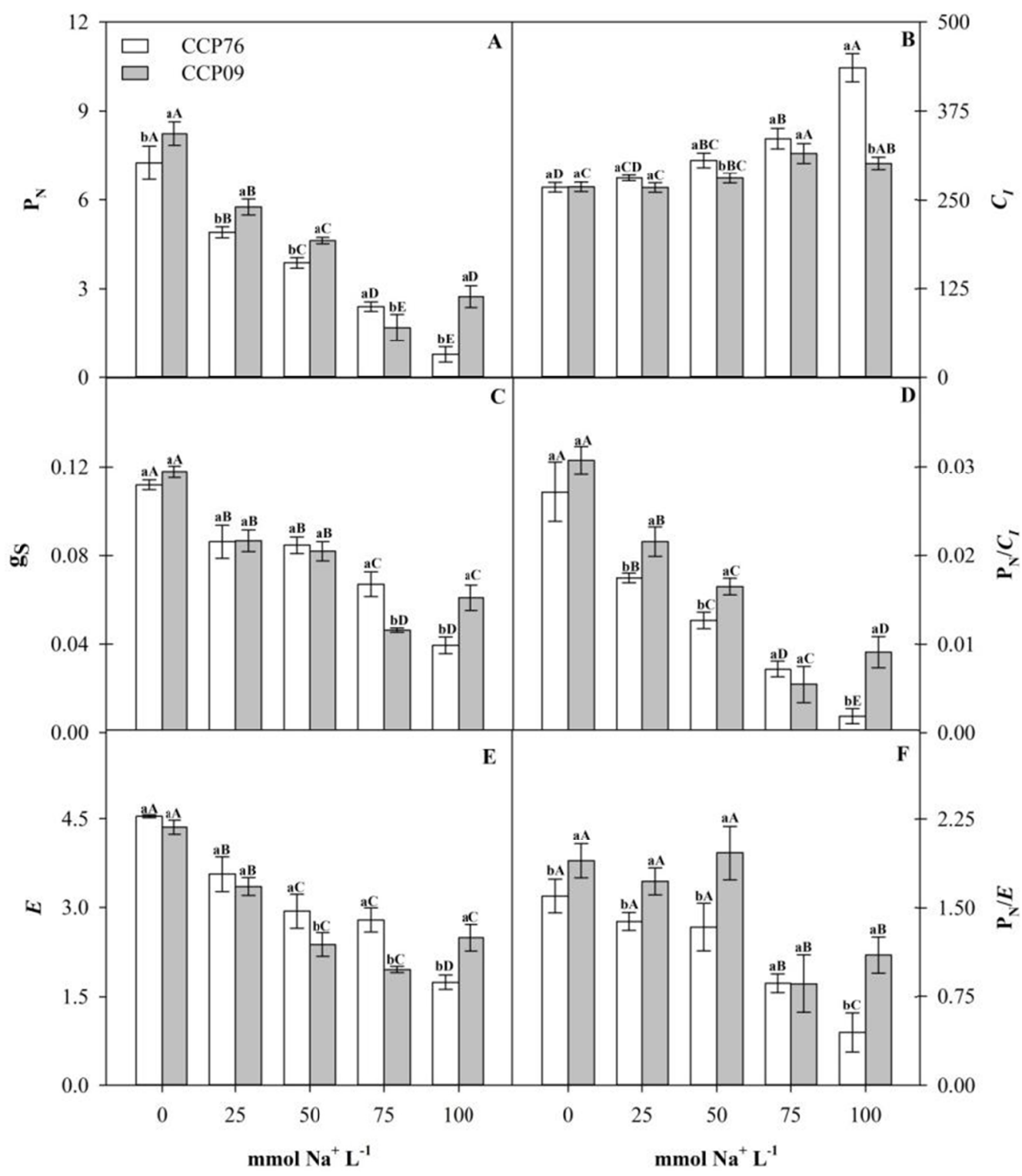

Figure 2. $\mathrm{CO}_{2}$ assimilation rate (PN) (A), intercellular $\mathrm{CO}_{2}$ concentration $(\mathrm{CI})(\mathrm{B})$, maximum carboxylation efficiency $\left(\mathrm{P}_{N} / \mathrm{C}_{I}\right)(\mathrm{C})$, stomatal conductance $(\mathrm{gS})(\mathrm{D})$, transpiration rate $(\mathrm{E})$ and water use efficiency $(\mathrm{PN} / \mathrm{E})(\mathrm{F})$ in the leaves of early dwarf cashew clones (CCP76 and CCP09) grown under controlled conditions with distilled water and treated with $0 ; 25 ; 50 ; 75$ and $100 \mathrm{mM} \mathrm{NaCl}$ for 30 days. The letters on the bars indicate significant differences according to the Tukey test $(\mathrm{p} \leq 0.05)$. Lowercase letters are associated with clones; and uppercase letters with doses salinas

Hussain et al. (2012) reported that the accumulation of salts in leaf affects stomatal closure due to the dehydration of guard cells. Similar results were observed in cashew seedlings exposed to both combined and isolated factors under high temperature and salinity (Ferreira-Silva et al., 2011). The same behavior was also reported in other species of plants exposed to salinity, such as Ipomoea pes-caprae (Suárez, 2011). However, Amorim, Gomes Filho, Bezerra, Prisco, and Lacerda (2010) reported varying results in clones CCP76 and CCP06 but no significant changes in $g_{S}$ when plants were exposed to salt stress with different electrical conductivities $(0.5 ; 4.0 ; 8.0$ and 12.0 $\mathrm{dS} \mathrm{m}^{-1}$ ).

The rate of $E$ decreased with increasing salt dose (Figure 2E), with mean reductions of $62.22 \%$ for clone CCP76 and $41.86 \%$ for CCP09 in the treatment with $100 \mathrm{mM} \mathrm{NaCl}$ compared to control. The decrease in the $E$ rate may be related to the reduction in $\mathrm{g}_{\mathrm{s}}$. A reduction in $\mathrm{g}_{\mathrm{S}}$ reduces water consumption through $E$ and contributes to water retention in leaves, which may be a key factor for avoiding drastic effects of drought on growth and 
photosynthesis of cashew seedlings. According to Carneiro et al. (2012), an increase in salinity causes a reduction in the transpiration rate of cashew clone CCP76 plants due to the osmotic effect of salinity stress, affecting mass flow to root zone.

A progressive reduction in $\mathrm{P}_{N} / \mathrm{E}$ in cashew leaves exposed to different concentrations of $\mathrm{Na}^{+}$(Figure $2 \mathrm{~F}$ ) was also observed. Clones were stable through the $50 \mathrm{mM} \mathrm{NaCl}$ dose, but there was a $60.16 \%$ reduction in $\mathrm{P}_{N} / E$ for the CCP76 clone and a $69 \%$ reduction for the CCP09 clone at concentrations of $100 \mathrm{mM} \mathrm{NaCl}$. However, CCP09 stood out more than CCP76 did in all salinity concentrations. This decrease in $\mathrm{P}_{N} / E$ can be explained by the reduction in $\mathrm{P}_{N}$ (Figure 2A), demonstrating the ability of plants to absorb and assimilate $\mathrm{CO}_{2}$ at the expense of water loss through evapotranspiration (Silva et al., 2014).

The apparent ETR was also influenced by $\mathrm{NaCl}$. In the CCP09 clone, the ETR remained constant through the dose of $50 \mathrm{mM}$ but decreased by $21.42 \%$ with dose of $100 \mathrm{mM}$ compared with to control (Figure 3A). In the CCP76 clone, there was an increase with the $25 \mathrm{mM}$ dose followed by a drastic reduction of $41.09 \%$ with the dose of 100 $\mathrm{mM} \mathrm{NaCl}$ compared to control. It is possible that the salinity directly affected PSII due to photoinhibitory processes, enabling the reduction in the electron flux necessary for the formation of ATP and NADPH (Ghannoum et al., 2003). Similar results have been reported in bean, corn, sorghum and Brachiaria (Dias \& Brüggemann, 2010; Santos et al., 2014) under water and salinity stresses.

Salinity stress also provided excess electrons for photosynthesis, as indicated by the increase in ETR/ $\mathrm{P}_{N}$. There was an increase in both clones, with increases of $81.81 \%$ in CCP76 at a dose of $100 \mathrm{mM}$ and of $78 \%$ in clone CCP09 through the dose of $75 \mathrm{mM} \mathrm{NaCl}$ compared with that of the controls (Figure 3B). The increase in the ETR/ $\mathrm{P}_{N}$ ratio indicated the occurrence of excess electrons for the carbon reduction process, a potential condition for the formation of excessive ROS.

The increase in the ETR $/ \mathrm{P}_{N}$ ratio represents an imbalance between electron flux and $\mathrm{P}_{N}$ during photosynthesis, which is often associated with an increase in the electron flux to other physiological processes rather than to reactions for $\mathrm{P}_{N}$ (Baker, Harbinson, \& Kramer, 2007; Ribeiro et al., 2009). The increase in the ETR/ $\mathrm{P}_{N}$ ratio is associated with a reduction in the $\mathrm{P}_{N} / \mathrm{C}_{I}$ ratio, which may indicate a loss in photosynthetic efficiency in cashew seedlings caused by salinity stress.

The maximum $\mathrm{Fv} / \mathrm{Fm}$ was reduced by 3\% (not significant) in both cashew clones (Figure 3C) from the treatment of $75 \mathrm{mM} \mathrm{NaCl}$. Jamil, Lee, J. M. Kim, H. S. Kim, and Rha (2007), and Silveira, S. L. Silva, E. N. Silva, and Viégas (2010) reported that salinity stress causes stomatal closure, which reduces photosynthesis and disturbs PSII functioning, causing reductions in maximum $\mathrm{Fv} / \mathrm{Fm}$ values in cashew tree seedlings, especially at high salinity concentrations $\left(14.1 \mathrm{dS} \mathrm{m}^{-1}\right)$. This reduction was also confirmed in studies of changes in photochemical reactions caused by salinity stress in glycophytes, reported by Cha-Um and Kirdmanee (2011), when comparing the results of potential $\mathrm{Fv} / \mathrm{Fm}$ in yellow passion fruit plants irrigated with saline water (Freire, Dias, Cavalcante, Fernandes, \& Lima-Neto, 2014).

The quantum efficiency of PSII ( $\triangle \mathrm{F} / \mathrm{Fm}$ ') decreased as salt levels increased, corresponding to a $37.5 \%$ reduction for the clone CCP76 and a 20\% reduction for the clone CCP09 exposed to $100 \mathrm{mM} \mathrm{NaCl}$ compared with that of the controls. However, an increase in $\Delta \mathrm{F} / \mathrm{Fm}$ ' under the $25 \mathrm{mM}$ treatment was noted, although a drastic reduction in Fv/Fm was observed under the higher salt regimes (Figure 3D). Similar results were observed in eucalyptus irrigated with saline water (Mendonça, Carneiro, Freitas, \& Barroso, 2010) and in cowpea under conditions of salinity stress (Souza et al., 2011), in which reductions in $\Delta \mathrm{F} / \mathrm{Fm}$ ' were observed.

Regarding qP, there was a 50\% decrease in the CCP76 clone from the $100 \mathrm{mM}$ dose compared with that of the control seedlings (Figure 3E). There was also a significant increase in $\mathrm{qP}$ in the CCP09 clone and a gradual reduction in qP under the $25 \mathrm{mM}$ dose, mainly in $\mathrm{CCP} 76$. At higher concentrations, $\mathrm{NaCl}$ led to a reduction in qP due to the accumulation of $\mathrm{Na}^{+}$and/or $\mathrm{Cl}^{-}$in the chloroplasts, negatively affecting the biochemical and photochemical processes involved in photosynthesis (Munns \& Tester 2008). An analysis of qP indicates the percentage of energy directed to photosynthesis, demonstrating PSII capacity to use light energy to reduce NADP ${ }^{+}$ (Ribeiro et al., 2009). In this work, the reduction of qP indicated that PSII and ETR is reduced too (Dias \& Brüggemann, 2010). The same effect has been observed in bean, corn, sorghum and Brachiaria under water stress and saline conditions (Souza et al., 2011; Santos et al., 2014). 


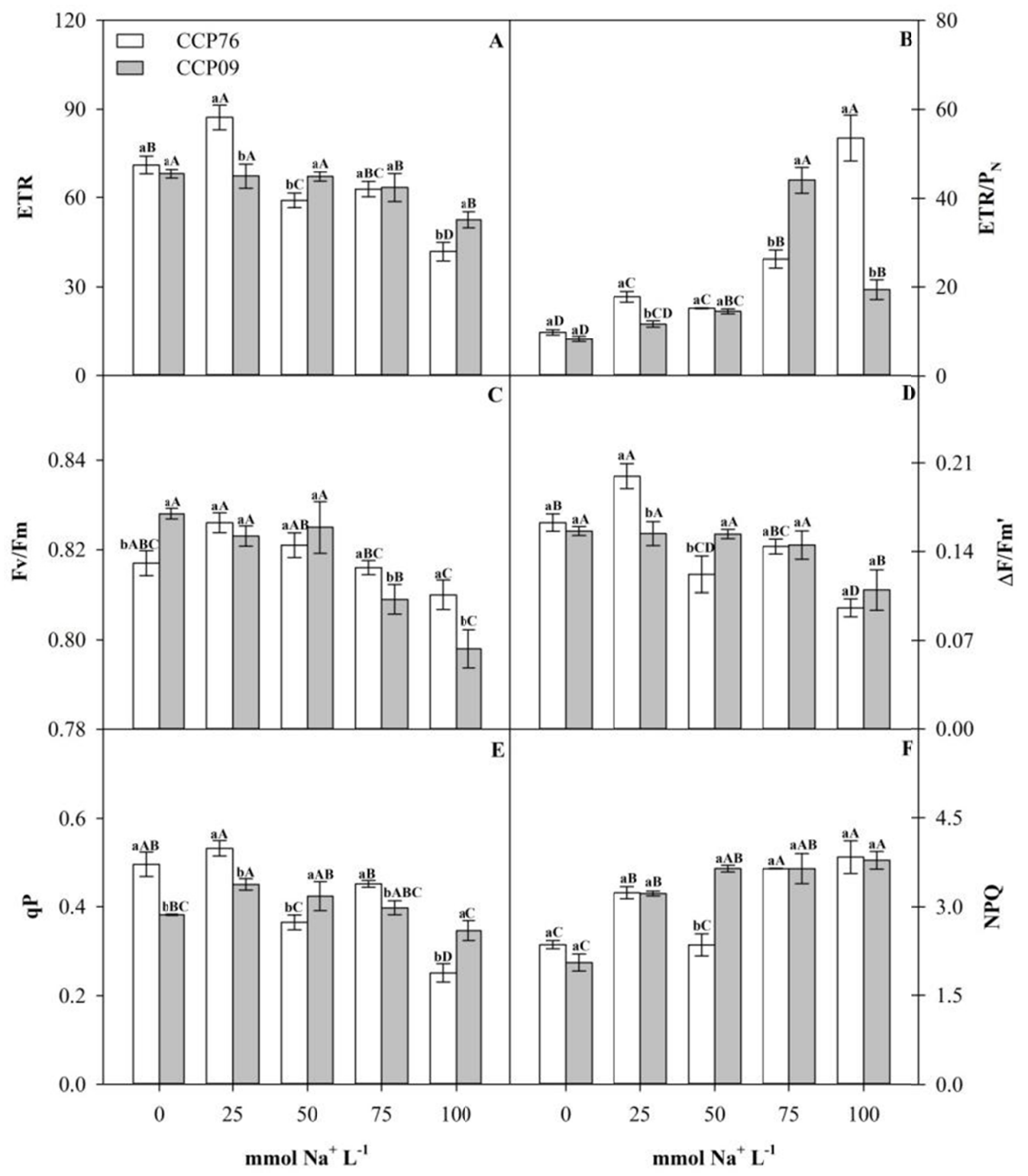

Figure 3. Apparent rate of electron transport (ETR) (A), excess electrons for photosynthesis $\left(E T R / \mathrm{P}_{\mathrm{N}}\right)(\mathrm{B})$, quantum efficiency of photosystem II (Fv/Fm) (E) and non-photochemical quenching (NPQ) (F) in the leaves of early dwarf cashew clones (CCP76 and CCP09) grown under control conditions with distilled water and treated

with $0 ; 25 ; 50 ; 75$ and $100 \mathrm{mM} \mathrm{NaCl}$ for 30 days. The letters on the bars indicate significant differences according to the Tukey test $(\mathrm{p} \leq 0.05)$. Lowercase letters are associated with the clones; and uppercase letters with doses salinas

The NPQ increased with increasing salinity, with the greatest influence from the dose of $100 \mathrm{mM} \mathrm{NaCl}$, reaching $33.33 \%$ in clone CCP76 and $43.24 \%$ in clone CCP09 compared with that of the respective controls (Figure 3F). The increase in NPQ is associated with non-photochemical energy dissipation mechanisms caused by reductions in both the effective Fv/Fm of PSII and qP, which is expected due to the reduction of $\mathrm{P}_{N}$ by salinity stress. After the exposure of cashew clones to salinity stress, the photochemical process became activated, providing energy transfer via NPQ proportional to the increase in salt dose.

\subsection{Oxidative Protection in Response to Salinity in Cashew Plants}

The cashew clones presented different $\mathrm{H}_{2} \mathrm{O}_{2}$ contents. In CCP76, treatment with $25 \mathrm{mM} \mathrm{NaCl}$ increased the content of $\mathrm{H}_{2} \mathrm{O}_{2}$ in the leaves by $30.76 \%$ compared with that of the controls, whereas under the other treatments, the $\mathrm{H}_{2} \mathrm{O}_{2}$ content remained similar to that of the control (Figure 4A). On the other hand, the CCP09 clone 
maintained a constant $\mathrm{H}_{2} \mathrm{O}_{2}$ content throughout the treatments, differing only from the $100 \mathrm{mM}$ dose, in which the $\mathrm{H}_{2} \mathrm{O}_{2}$ increased by $36 \%$. The excessive accumulation of $\mathrm{H}_{2} \mathrm{O}_{2}$ in plant tissues is indicative of the overproduction of ROS originating from metabolic disturbances caused by salinity stress (Daneshmand, Arvin, \& Kalantari, 2010; Hernandez, Fernandez-Garcia, Diaz-Vivancos, \& Olmos, 2010). The results, however, differ from those of Ferreira-Silva et al. (2012), in which the contents of $\mathrm{H}_{2} \mathrm{O}_{2}$ in cashew tree leaves subjected to different concentrations of $\mathrm{NaCl}(0 ; 50 ; 150$ and $200 \mathrm{mM})$ presented no significant effects.

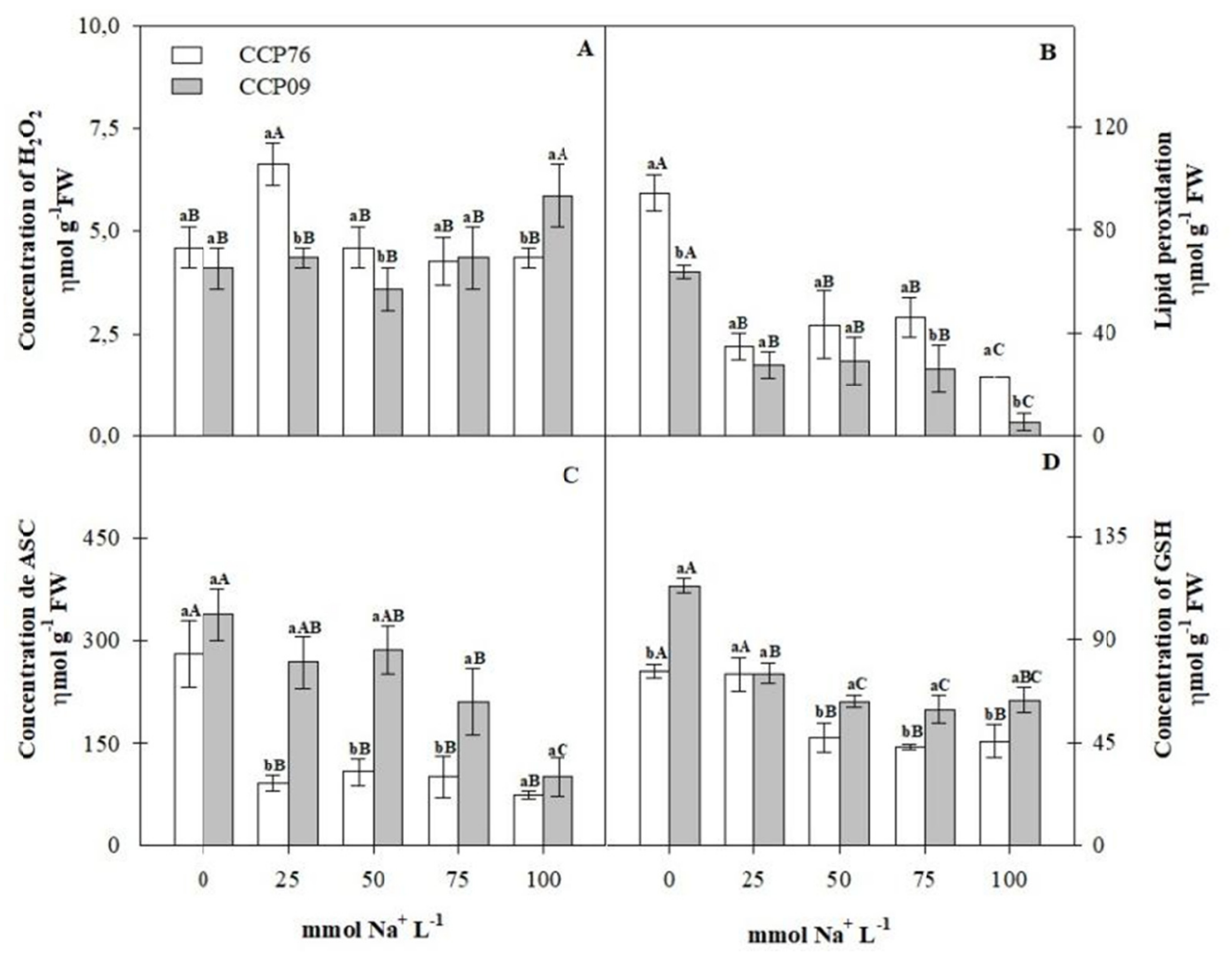

Figure 4. $\mathrm{H}_{2} \mathrm{O}_{2}$ concentration (A), lipid peroxidation (thiobarbituric acid [TBARS]) (B), ascorbate concentration (ASC) (C) and glutathione (GSH) reductase concentration (D) in the leaves of early dwarf cashew clones (CCP76 and CCP09) grown under control conditions with distilled water and treated with $0 ; 25 ; 50 ; 75$ and 100 $\mathrm{mM} \mathrm{NaCl}$ for 30 days. The letters on the bars indicate significant differences according to the Tukey test $(\mathrm{p} \leq$ 0.05). Lowercase letters are associated with the clones; and uppercase letters with doses salinas

It was noted that in seedlings subjected to salinity there was an intense reduction in TBARS content (Figures 4B). The TBARS content was reduced by $68.42 \%$ in CCP76 and $84.61 \%$ in CCP09 compared to control. Similar results were reported by Ferreira-Silva et al. (2012) in which the TBARS content in cashew tree leaves decreased proportionally to increasing salt dose. These results suggest that cashew tree seedlings under salinity stress may have efficient mechanisms to restore damaged membrane lipids and/or to remove produced ROS, which is favorable for oxidative protection. Similar results were obtained in the roots of cowpea beans (Maia et al., 2012) and in cashew tree leaves (Ferreira-Silva et al., 2012).

Analogous to lipid peroxidation, contents of non-enzymatic antioxidants, ASC and GSH, experienced drastic changes in response to salinity stress (Figures $4 \mathrm{C}$ and $4 \mathrm{D}$ ). The $\mathrm{NaCl}$ treatments reduced the ASC content in cashew tree leaves, with drastic decreases of $71.42 \%$ for CCP76 and $73.52 \%$ for CCP09 at the concentration of $100 \mathrm{mM}$. However, CCP09 had higher concentrations of reduced ASC at doses of $25 ; 50$ and $75 \mathrm{mM}(67 \%$, on average) relative to those of CCP76 (Figures 4C and 4D).

According to Noctor and Foyer (1998), ASC is considered the main antioxidant substrate for $\mathrm{H}_{2} \mathrm{O}_{2}$ reduction. Since APX uses two reduced ASC molecules as electron-specific donors to catalyze the reduction of a molecule of $\mathrm{H}_{2} \mathrm{O}_{2}$ to $\mathrm{H}_{2} \mathrm{O}$ and $\mathrm{O}_{2}$, ASC is an essential metabolite involved in the oxidative metabolism and maintenance of vital cellular functions (Nakano \& Asada, 1987; Gratão, Polle, Lea, \& Azevedo, 2005). In the present study, the 
ASC content in CCP76 was inversely proportional to the APX activity, supporting the hypothesis of the efficient interaction of the enzymatic and non-enzymatic antioxidant mechanisms in the oxidative protection of cashew plants under saline conditions.

In the CCP09 clone, the high amounts of reduced ASC content associated with low APX activity indicated ASC consumption decreased, suggesting a role of ASC in the oxidative protection of this clone. Similar results were observed in cashew trees (Ferreira-Silva et al., 2012) and corn plants (Shan, Liu, Zhao, \& Wang, 2014), in which the reduction of the ASC redox state, which is associated with a decrease in APX activity under high $\mathrm{NaCl}$ concentrations, may indicate the direct use of ASC in $\mathrm{H}_{2} \mathrm{O}_{2}$ oxidation.

The content of GSH in the leaf tissue decreased with increasing salinity, mainly from $50 \mathrm{mM} \mathrm{NaCl}$ (Figure 4D). In both clones, there was a drastic reduction in GSH content (38.66\% for CCP76 and $42.60 \%$ for CCP09) under $100 \mathrm{mM} \mathrm{NaCl}$ stress compared to control. However, CCP09 was more responsive than was CCP76 and exhibited $34.78 \%$ more GSH than did CCP76 compared to control and an average decrease of 30\% in GSH concentration under treatments of 50,75 and $100 \mathrm{mM} \mathrm{NaCl}$ (Figure 4D). GSH is considered the main thiol compound that promotes protection against ROS (Foyer \& Noctor, 2003; Tausz, Šircelj, \& Grill, 2004; Delaplace, Fauconnier, \& DuJardin, 2011). In this study, the reduction in ASC and GSH was directly proportional to the reduction in TBARS, corroborating the hypothesis that these molecules are important for antioxidant protection in plants. This effect was also observed in Vigna radiata (Shan \& Zhao, 2014) and Zea mays (Shan, Liu, Zhao, \& Wang, 2014).

However, enzymatic responses were visually clone specific, with CCP76 presenting higher activities of SOD and APX but lower POX activity; for CCP09, there was a significant increase in POX activity (Figures 5A, 5B, and 5C). Salt treatment caused changes in leaf SOD activity in both clones. SOD activity increased significantly only in the CCP76 clone, with a $24.39 \%$ increase at the dose of $75 \mathrm{mM} \mathrm{NaCl}$ compared to control (Figure $5 \mathrm{~A}$ ). In addition, regarding the stability of $\mathrm{H}_{2} \mathrm{O}_{2}$ and the decrease in TBARS, it is suggested that these plants did not undergo oxidative stress and that the maintenance of ROS content is due to the action of antioxidants other than SOD. Similar results have been reported in species such as Zea mays (Kholova, Sairam, \& Meena, 2010) and Saccharum officinarum (Satbhai \& Naik, 2014).

APX activity was significantly distinct between clones. The APX content significantly decreased only in CCP76, with a decrease of $85.71 \%$ with the dose of $100 \mathrm{~mm} \mathrm{NaCl}$ compared to control (Figure 5B). However, clones differed by $81 \%$ on average from the doses of $0 ; 25 ; 50$ and $75 \mathrm{~mm} \mathrm{NaCl}$. The effects of salt on the decrease in APX activity in plants has been previously reported (Ferreira-Silva et al., 2012; Maia et al., 2012). Ferreira-Silva et al. (2012) suggested that this decrease in APX activity of cashew trees is caused by an association to eliminate ROS.

POX activity gradually increased in both clones (Figure 5C). In particular, in the CCP76 clone, the POX activity increased by $32.14 \%$ from the $25 \mathrm{mM}$ dose, and the CCP09 clone increased by $21 \%$ from the treatment of 75 $\mathrm{mM}$, both compared to control. However, the activity of this enzyme in the shoots was $35 \%$ higher on average in CCP09 than in CCP76 at all doses. POX has been associated with antioxidant protection against diverse abiotic stresses (Abdelgawad, Khalafaallah, \& Abdallah, 2014; Laxman et al., 2014) and the control of growth under various conditions of stress (Maia et al., 2012). In the present work, the significant increase in POX activity may be related, at least in part, to the decrease in accumulation of biomass in cashew tree shoots, given the early maturation of tissues caused by increased POX activity. This effect has also been observed in Arabidopsis (Mhamdi, Noctor, \& Baker, 2012) and cowpea (Maia et al., 2012).

Taken together, the increased activity of these enzymes indicates antioxidant protective function against salinity stress (Harter, Harter, Deuner, Meneghello, \& Villela, 2014). However, in the present work, POX apparently represents low relevance in the process of maintaining the ROS pool in cashew trees, due to its low responsiveness to increased salt dose and subtle relationship with the peroxidation of lipids. 


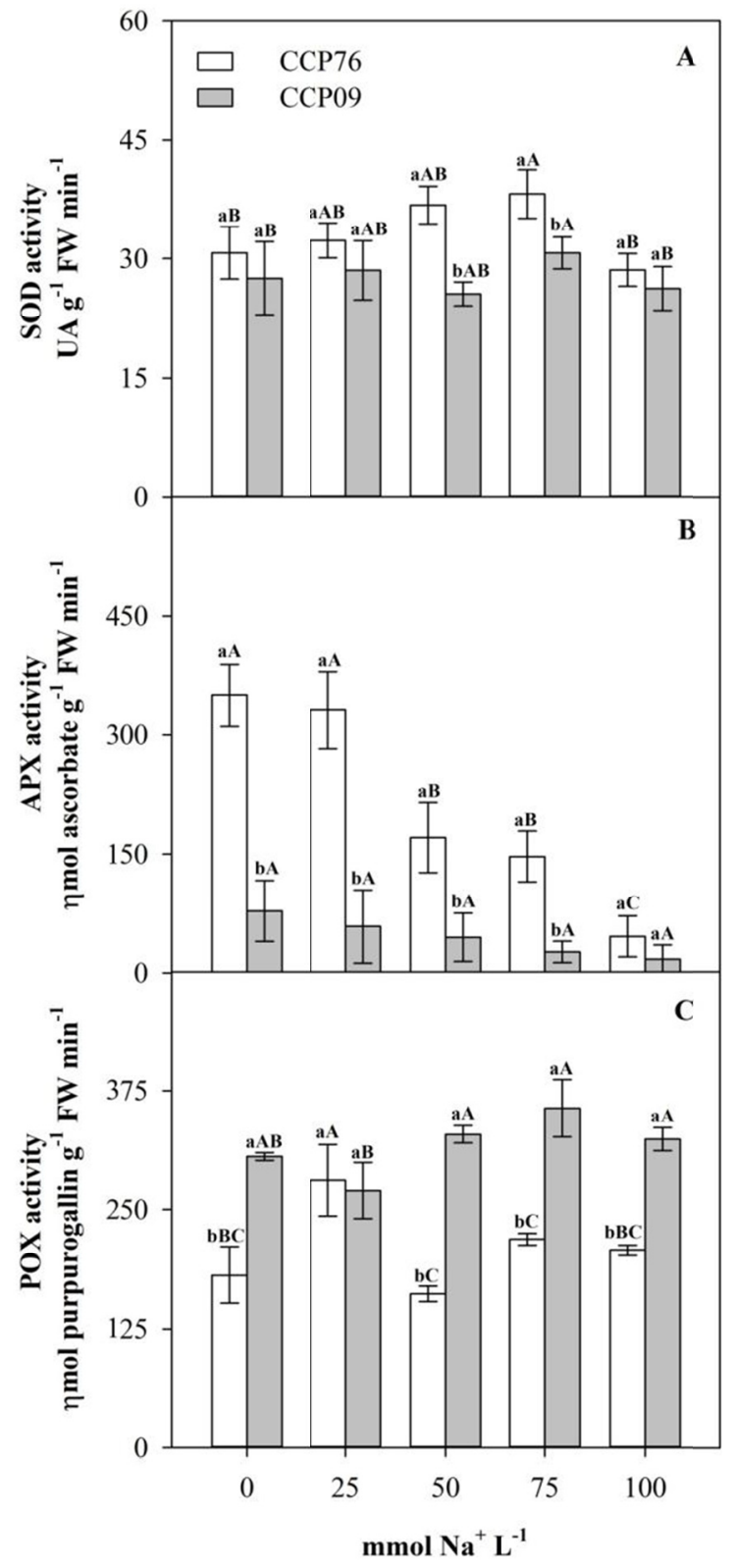

Figure 5. Superoxide dismutase (SOD) (A), ascorbate peroxidase (APX) (B) and phenol peroxidase (POX) (C) activity in the leaves of early dwarf cashew clones (CCP76 and CCP09) grown under control conditions with distilled water and treated with $0 ; 25 ; 50 ; 75$ and $100 \mathrm{mM} \mathrm{NaCl}$ for 30 days. The letters on the bars indicate significant differences according to the Tukey test $(\mathrm{p} \leq 0.05)$. Lowercase letters are associated with the clones; and uppercase letters with doses Salinas

In cashew plants, high doses of $\mathrm{NaCl}$ did not drastically affect the fresh mass of above ground portions, despite showing ionic toxicity, as evaluated by the $\mathrm{K}^{+} / \mathrm{Na}^{+}$ratio. The photosynthetic efficiency of cashew plants was affected by salinity, mainly by dramatic reductions in $\mathrm{P}_{N}, \mathrm{P}_{N} / \mathrm{C}_{I}$ and $\mathrm{g}_{\mathrm{s}}$. The last one is possibly related to the lower efficiency regarding the mobilization of $\mathrm{K}^{+}$. Additionally, mechanisms of antioxidant protection are clone specific, as there was a tendency of enzymatic responses in clone CCP76 and non-enzymatic responses, besides the high activity of POX, in CCP09. Taken together, results suggest that the best photosynthetic performance was in the CCP09 clone. CCP09 exhibited greater efficiency of $\mathrm{P}_{N}$ and water use in its tissues than did CCP76 due to the protective effect of $\mathrm{K}^{+}$on leaves and to relevant non-enzymatic antioxidant protection promoted by ASC and $\mathrm{GSH}$, in addition to the enzymatic activity of POX. 


\section{Acknowledgements}

The authors thank the Coordenação de Aperfeiçoamento de Pessoal de Nível Superior (CAPES) for the scholarships of A. F. Silva, V. F. O. Sousa, G. L. Santos, and E. S. Araújo-Júnior. Also thank the Conselho Nacional de Desenvolvimento Científico e Tecnológico (CNPq) for the financing of Universal Project No. 485799/2013-8.

\section{References}

Abbaspour, N., Kaiser, B., \& Tyerman, S. (2014). Root apoplastic transport and water relations cannot account for differences in $\mathrm{Cl}^{-}$transport and $\mathrm{Cl}^{-} / \mathrm{NO}_{3}{ }^{-}$interactions of two grapevine rootstocks differing in salt tolerance. Acta Physiology Plantarum, 36(3), 687-698. https://doi.org/10.1007/s11738-013-1447-y

Abdelgawad, Z. A., Khalafaallah, A. A., \& Abdallah, M. M. (2014). Impact of methyl jasmonate on antioxidant activity and some biochemical aspects of maize plant grown under water stress condition. Agricultural Sciences, 5(12), 1077-1088. https://doi.org/10.4236/as.2014.512117

Amorim, A. V., Gomes Filho, E., Bezerra, M. A., Prisco, J. T., \& Lacerda, C. F. (2010). Respostas fisiológicas de plantas adultas de cajueiro anão precoce à salinidade. Revista Ciência Agronômica, 41(1), 113-121.

Baker, N. R., Harbinson, J., \& Kramer, D. M. (2007). Determining the limitations and regulation of photosynthetic energy transduction in leaves. Plant, Cell \& Environment, 30(9), 1107-1125. https://doi.org/ 10.1111/j.1365-3040.2007.01680.x

Beauchamp, C., \& Fridovich, I. (1971). Superoxide dismutase: Improved assays and an assay applicable to acrylamide gels. Analytical Biochemistry, 44(1), 276-287. https://doi.org/10.1016/0003-2697(71)90370-8

Bessa, M. C., Lacerda, C. F., Amorim, A. V., Bezerra, A. M. E., \& Lima, A. D. (2017). Mechanisms of salt tolerance in seedlings of six woody native species of the Brazilian semi-arid. Revista Ciência Agronômica, 48(1), 157-165. https://doi.org/10.5935/1806-6690.20170018

Bhattacharjee, S. (2010). Sites of generation and physicochemical basis of formation of reactive oxygen species in plant cell. In S. D. Gupta (Ed.), Reactive oxygen species and antioxidants in higher plants. Enfield, Science Publishers. https://doi.org/10.1201/9781439854082-2

Carneiro, P. T., Fernandes, P. D., Gheyi, H. R., Soares, F. A., Santos, M. A., \& Feitoza, L. A. (2012). Evapotranspiração do cajueiro anão precoce sob estresse salino em diferentes fases fenológicas. Irriga., 1(1), 351-367. https://doi.org/10.15809/irriga.2012v1n01p351

Cha-um, S., \& Kirdmanee, C. (2011). Remediation of salt-affected soil by the addition of organic matter: An investigation into improving glutinous rice productivity. Scientia Agrícola, 68(4), 406-410. https://doi.org/ $10.1590 / \mathrm{S} 0103-90162011000400003$

Chaves, M. M., Flexas, J., \& Pinheiro, C. (2009). Photosynthesis under drought and salt stress: Regulation mechanisms from whole plant to cell. Annals of Botany, 103(4), 551-560. https://oi.org/10.1093/aob/ $\operatorname{men} 125$

Cheeseman, J. M. (2006). Hydrogen peroxide concentrations in leaves under natural conditions. Journal of Experimental Botany, 57(10), 2435-2444. https://doi.org/10.1093/jxb/erl004

Chen, S., Hawighorst, P., Sun, J., \& Polle, A. (2014). Salt tolerance in Populus: Significance of stress signaling networks, mycorrhization, and soil amendments for cellular and whole-plant nutrition. Environmental and Experimental Botany, 107, 113-124. https://doi.org/10.1016/j.envexpbot.2014.06.001

Daneshmand, F., Arvin, M. J., \& Kalantari, K. M. (2010). Acetylsalicylic acid ameliorates negative effects of $\mathrm{NaCl}$ or osmotic stress in Solanum stoloniferum in vitro. Biologia Plantarum, 54(4), 781-784. https://doi.org/10.1007/s10535-010-0142-8

Delaplace, P., Fauconnier, M. L., \& DuJardin, P. (2011). Antioxidants involvement in the ageing of non-green organs: The potato tuber as a model. In S. D. Gupta (Ed.), Reactive oxygen species and antioxidants in higher plants (Vol. 8). New Hampshire, Science Publishers.

Dias, M. C., \& Brüggemann, W. (2010). Limitations of photosynthesis in Phaseolus vulgaris under drought stress: Gas exchange, chlorophyll fluorescence and Calvin cycle enzymes. Photosynthetica, 48(1), 96-102. https://doi.org/10.1007/s11099-010-0013-8 
Dinakar, C., Djilianov, D., \& Bartels, D. (2012). Photosynthesis in desiccation tolerant plants: Energy metabolism and antioxidative stress defense. Plant Science, 182, 29-41. https://doi.org/10.1016/j.plantsci. 2011.01 .018

Ferreira-Silva, S. L., Silva, E. N., Carvalho, F. E. L., de Lima, C. S., Alves, F. A. L., \& Silveira, J. D. (2010). Physiological alterations modulated by rootstock and scion combination in cashew under salinity. Scientia Horticulturae, 127(1), 39-45. https://doi.org/10.1016/j.scienta.2010.09.010

Ferreira-Silva, S. L., Silveira, J. A., Voigt, E. L., Soares, L. S., \& Viégas, R. A. (2008). Changes in physiological indicators associated with salt tolerance in two contrasting cashew rootstocks. Brazilian Journal of Plant Physiology, 20(1), 51-59. https://doi.org/10.1590/S1677-04202008000100006

Ferreira-Silva, S. L., Voigt, E. L., Silva, E. N., Maia, J. M., Aragão, T. C., \& Silveira, J. A. (2012). Partial oxidative protection by enzymatic and non-enzymatic components in cashew leaves under high salinity. Biologia Plantarum, 56, 172-176. https://doi.org/10.1007/s10535-012-0037-y

Ferreira-Silva, S. L., Voigt, E. L., Silva, E. N., Maia, J. M., Fontenele, V. A., \& Silveira, J. A. G. (2011). High temperature positively modulates oxidative protection in salt-stressed cashew plants. Environmental and Experimental Botany, 74, 162-170. https://doi.org/10.1016/j.envexpbot.2011.05.015

Ferreira-Silva, S. L., Voigt, E. L., Viégas, R. A., Paiva, J. D., \& Silveira, J. D. (2009). Influência de porta-enxertos na resistência de mudas de cajueiro ao estresse salino. Pesquisa Agropecuária Brasileira, 44, 361-367. https://doi.org/10.1590/S0100-204X2009000400005

Foyer, C. H., \& Noctor, G. (2003). Redox sensing and signalling associated with reactive oxygen in chloroplasts, peroxisomes and mitochondria. Physiologia Plantarum, 119, 355-364. https://doi.org/10.1034/j.1399 $-3054.2003 .00223 . \mathrm{x}$

Freire, J. L. O., Dias, T. J., Cavalcante, L. F., Fernandes, P. D., \& Lima Neto, A. J. (2014). Rendimento quantico e trocas gasosas em maracujazeiro amarelo sob salinidade hidrica, biofertilização e cobertura morta. Revista Ciência Agronômica, 45(1), 82-91. https://doi.org/10.1590/S1806-66902014000100011

Freitas, V. S., Marques, E. C., Bezerra, M. A., Prisco, J. T., \& Gomes-Filho, E. (2013). Crescimento e acúmulo de íons em plantas de cajueiro anão precoce em diferentes tempos de exposição à salinidade. Semina: Ciências Agrárias, 34(6), 3341-3352. https://doi.org/10.5433/1679-0359.2013v34n6Supl1p3341

Ghannoum, O., Conroy, J. P., Driscoll, S. P., Paul, M. J., Foyer, C. H., \& Lawlor, D. W. (2003). Nonstomatal limitations are responsible for drought - induced photosynthetic inhibition in four C4 grasses. New Phytologist, 159, 599-608. https://doi.org/10.1046/j.1469-8137.2003.00835.x

Giannopolitis, C. N., \& Ries, S. K. (1977). Superoxide dismutases I. Occurrence in higher plants. Plant Physiology, 59, 309-314. https://doi.org/10.1104/pp.59.2.309

Goh, C. H., Ko, S. M., Koh, S., Kim, Y. J., \& Bae, H. J. (2012). Photosynthesis and environments: Photoinhibition and repair mechanisms in plants. Journal of Plant Biology, 55(2), 93-101. https://doi.org/10. 1007/s12374-011-9195-2

Gratão, P. L., Polle, A., Lea, P. J., \& Azevedo, R. A. (2005). Making the life of heavy metal-stressed plants a little easier. Functional Plant Biology, 32, 481-494. https://doi.org/10.1071/FP05016

Griffith, O. W. (1980). Determination of glutathione and glutathione disulfide using glutathione reductase and 2-vinylpyridine. Analytical Biochemistry, 106(1), 207-212. https://doi.org/10.1016/0003-2697(80)90139-6

Harter, L. D. S. H., Harter, F. S., Deuner, C., Meneghello, G. E., \& Villela, F. A. (2014). Salinidade e desempenho fisiológico de sementes e plântulas de mogango. Horticultura Brasileira, 32(1), 80-85. https://doi.org/10.1590/S0102-05362014000100013

Heath, R. L., \& Packer, L. (1968). Photoperoxidation in isolated chloroplasts: I. Kinetics and stoichiometry of fatty acid peroxidation. Archives of Biochemistry and Biophysics, 125(1), 189-198. https://doi.org/10.1016/ 0003-9861(68)90654-1

Hernandez, M., Fernandez-Garcia, N., Diaz-Vivancos, P., \& Olmos, E. (2010). A different role for hydrogen peroxide and the antioxidative system under short and long salt stress in Brassica oleracea roots. Journal of Experimental Botany, 61(12), 521-535. https://doi.org/10.1093/jxb/erp321

Hoagland, D. R., \& Arnon, D. I. (1950). The water-culture method for growing plants without soil. Berkeley, California Agricultural Experiment Station. 
Hussain, S., Luro, F., Costantino, G., Ollitrault, P., \& Morillon, R. (2012). Physiological analysis of salt stress behaviour of citrus species and genera: Low chloride accumulation as an indicator of salt tolerance. South African Journal of Botany, 81, 103-112. https://doi.org/10.1016/j.sajb.2012.06.004

IBGE. (2016). Levantamento sistemático da produção agrícola. Safra. Retrieved from http://www.ibge.gov.br

Jamil, M., Lee, K. J., Kim, J. M., Kim, H. S., \& Rha, E. S. (2007). Salinity reduced growth PS2 photochemistry and chlorophyll content in radish. Scientia Agricola, 64(2), 111-118. https://doi.org/10.1590/S0103-90162 007000200002

Kampfenkel, K., Vanmontagu, M., \& Inze, D. (1995). Extraction and determination of ascorbate and dehydroascorbate from plant tissue. Analytical Biochemistry, 225(1), 165-167. https://oi.org/10.1006/ abio.1995.1127

Kar, M., \& Mishra, D. (1976). Catalase, peroxidase, and polyphenoloxidase activities during rice leaf senescence. Plant Physiology, 57, 315-319. https://doi.org/10.1104/pp.57.2.315

Khan, M. H., \& Panda, S. K. (2008). Alterations in root lipid peroxidation and antioxidative responses in two rice cultivars under NaCl-salinity stress. Acta Physiologiae Plantarum, 30, 81-89. https://oi.org/10.1007/ s11738-007-0093-7

Kholova, J., Sairam, R. K., \& Meena, R. C. (2010). Osmolytes and metal ions accumulation, oxidative stress and antioxidant enzymes activity as determinants of salinity stress tolerance in maize genotypes. Acta Physiologiae Plantarum, 32(3), 477-486. https://doi.org/10.1007/s11738-009-0424-y

Laxman, R. H., Rao, N. K. S., Biradar, G., Sunoj, V. S. J., Shivashankara, K. S., Pavithra, C. B., ... A. T., Christopher, M. G. (2014). Antioxidant enzymes activity and physiological response of tomato (Lycopersicon esculentum M.) genotypes under mild temperature stress. Indian Journal of Plant Physiology, 19(2), 161-164. https://doi.org/10.1007/s40502-014-0091-X

Lima, G. S. D., Nobre, R. G., Gheyi, H. R., Soares, L. A. D. A., \& Silva, A. O. D. (2014). Growth and components of production of castor bean under saline stress and nitrogen fertilization. Engenharia Agrícola, 34(5), 854-866. https://doi.org/10.1590/S0100-69162014000500005

Maia, J. M., Ferreira-Silva, S. L., Voigt, E. L., Macedo, C. D., Ponte, L. F. A., \& Silveira, J. A. G. (2012). Atividade de enzimas antioxidantes e inibição do crescimento radicular de feijão caupi sob diferentes níveis de salinidade. Acta Botanica Brasilica, 26(2), 342-349. https://doi.org/10.1590/S0102-33062012000200010

Malavolta, E., Vitti, G. C., \& Oliveira, S. A. (1989). Avaliação do estado nutricional das plantas. Piracicaba, POTAFOS.

Marques, E. C., Freitas, V. S., Bezerra, M. A., Prisco, J. T., \& Gomes-Filho, E. (2011). Efeitos do estresse salino na germinação, emergência e estabelecimento da plântula de cajueiro anão precoce. Revista Ciência Agronômica, 42(4), 993-999. https://doi.org/10.1590/S1806-66902011000400023

Mendonça, A. V. R., Carneiro, J. G. A., Freitas, T. A. S., \& Barroso, D. G. (2011). Características fisiológicas de mudas de Eucalyptus spp. submetidas a estresse salino. Ciência Florestal, 20(2), 255-267.

Mhamdi, A., Noctor, G., \& Baker, A. (2012). Plant catalases: Peroxisomal redox guardians. Archives of Biochemistry and Biophysics, 525(2), 181-194. https://doi.org/10.1016/j.abb.2012.04.015

Mittler, R. (2002). Oxidative stress, antioxidants and stress tolerance. Trends in Plant Science, 7, $405-410$. https://doi.org/10.1016/S1360-1385(02)02312-9

Munns, R., \& Tester, M. (2008). Mechanisms of salinity tolerance. Annual Review of Plant Biology, 59, 651-681. https://doi.org/10.1146/annurev.arplant.59.032607.092911

Nakano, Y., \& Asada, K. (1981). Hydrogen peroxide is scavenged by ascorbate-specific peroxidase in spinach chloroplasts. Plant \& Cell Physiology, 22(5), 867-880.

Nakano, Y., \& Asada, K. (1987). Purification of ascorbate peroxidase in spinach chloroplasts; its inactivation in ascorbate-depleted medium and reactivation by monodehydroascorbate radical. Plant \& Cell Physiology, 28(1), 131-140.

Noctor, G., \& Foyer, C. H. (1998). Ascorbate and glutathione: keeping active oxygen under control. Annual Review of Plant Biology, 49, 249-279. https://doi.org/10.1146/annurev.arplant.49.1.249 
Ponte, L. F. A., Ferreira, O. S., Alves, F. A. L., Ferreira-Silva, S. L., Pereira, V. L. A., \& Silveira, J. D. (2011). Variabilidade de indicadores fisiológicos de resistência à salinidade entre genótipos de cajueiro-anão e gigante. Pesqusa Agropecuária Brasileira, 46(1), 1-8. https://doi.org/10.1590/S0100-204X2011000100001

Ribeiro, R. V., Machado, E. C., Santos, M. G., \& Oliveira, R. F. (2009). Photosynthesis and water relations of well-watered orange plants as affected by winter and summer conditions. Photosynthetica, 47(2), $215-222$. https://doi.org/10.1007/s11099-009-0035-2

Ribeiro, R., Santos, M. G., Machado, E. C., \& Oliveira, R. F. (2008). Photochemical heat-shock response in common bean leaves as affected by previous water deficit. Russian Journal of Plant Physiology, 55, 350-358. https://doi.org/10.1134/S1021443708030102

Rodrigues, C. R. F., Silva, E. N., Ferreira-Silva, S. L., Voigt, E. L., Viégas, R. A., \& Silveira, J. A. G. (2013). High $\mathrm{K}^{+}$supply avoids $\mathrm{Na}^{+}$toxicity and improves photosynthesis by allowing favorable $\mathrm{K}^{+}: \mathrm{Na}^{+}$ratios through the inhibition of $\mathrm{Na}^{+}$uptake and transport to the shoots of Jatropha curcas plants. Jornal of Plant Nutrcional Soil Scince, 176, 157-164. https://doi.org/10.1002/jpln.201200230

Rohácek, K. (2002). Chlorophyll fluorescence parameters: the definitions, photosynthetic meaning, and mutual relationships. Photosynthetica, 40(1), 13-29. https://doi.org/10.1023/A:1020125719386

Romero-Aranda, R., Moya, J. L., Tadeo, F. R., Lagaz, F., Primomillo, E., \& Talon, M. (1998). Physiological and anatomical disturbances induced by chloride salts in sensitive and tolerant citrus: beneficial and detrimental effects of cations. Plant \& Cell Environment, 21, 1243-1253. https://doi.org/10.1046/j.1365-3040.1998.003 49.x

Santos, O. O., Falcão, H., Antonino, A. C. D., Lima, J. R. S., Lustosa, B. M., \& Santos, M. G. (2014). Desempenho ecofisiológico de milho, sorgo e braquiária sob déficit hídrico e reidratação. Bragantia, 73(2), $203-212$. https://doi.org/10.1590/brag.2014.018

Satbhai, R. D., \& Naik, R. M. (2014). Osmolytes accumulation, cell membrane integrity, and antioxidant enzymes in sugarcane varieties differing in salinity tolerance. Sugar Tech, 16(1), 30-35. https://doi.org/10.1007/s12 355-013-0243-8

Schreiber, U., Bilger, \& W., Neubauer, C. (1994). Chlorophyll fluorescence as a nonintrusive indicator for rapid assessment of in vivo photosynthesis. In E. D. Schulze, \& M. M. Caldwell (Eds.), Ecophysiology of photosynthesis. Berlin, Springer.

Shaheen, S., Naseer, S., Ashraf, M., \& Akram, N. A. (2013). Salt stress affects water relations, photosynthesis, and oxidative defense mechanisms in Solanum melongena L. Journal of Plant Interactions, 8(1), 85-96. https://doi.org/10.1080/17429145.2012.718376

Shan, C., \& Zhao, X. (2014). Effects of lanthanum on the ascorbate and glutathione metabolism of Vigna radiata seedlings under salt stress. Biologia Plantarum, 58(3), 595-599. https://doi.org/10.1007/s10535-014-0413-X

Shan, C., Liu, H., Zhao, L., \& Wang, X. (2014). Effects of exogenous hydrogen sulfide on the redox states of ascorbate and glutathione in maize leaves under salt stress. Biologia Plantarum, 58(1), 169-173. https://doi.org/10.1007/s10535-013-0366-5

Shavrukov, Y. (2013). Salt stress or salt shock: Which genes are we studying? Journal of Expeimental Botay, 64, 119-127. https://doi.org/10.1093/jxb/ers316

Shi, L., Meng-Zhaolai, M. A. S., Wang, Y., Xu, M., \& Xu, J. (2015). Growth and Photosynthetic Characteristics of Glycine GracilisSeedings under Different Types of Saline Stresses. Pakistan Journal of Botany, 47, 819-828.

Silva, A. G., Guarnieri, A., \& Silva, J. T. (2016). Production and nutritional characteristics of sunflowers and paiaguas palisadegrass under different forage systems in the off season. Bioscience Journal, 32(2), 460-470.

Silva, L. A., Brito, M. E. B., Sá, F. D. S., Moreira, R. C. L., Soares Filho, W. D. S., \& Fernandes, P. D. (2014). Mecanismos fisiológicos de percepção do estresse salino de híbridos de porta-enxertos citros em cultivo hidropônico. Revista Brasileira de Engenharia Agrícola, 18, 3981-3990. https://doi.org/10.12702/ii.inov agri.2014-a533

Silveira, J. A. G., \& Carvalho, F. E. L. (2016). Proteomics, photosynthesis and salt resistance in crops: An integrative view. Journal of Proteomics, 143, 24-35. https://doi.org/10.1016/j.jprot.2016.03.013

Silveira, J. A., Silva, S. L., Silva, E. N., \& Viégas, R. A. (2010). Mecanismos biomoleculares envolvidos com a resistência ao estresse salino em plantas. In H. R. Gheyi, N. S. Dias, \& C. F. Lacerda (Eds.), Manejo da salinidade na agricultura: estudos básicos e aplicados. INCTSal, Fortaleza. 
Šimková, L., Fialová, I., Vaculíková, M., \& Luxová, M. (2016). The Effect of Silicon on the Activity and Isozymes Pattern of Antioxidative Enzymes of Young Maize Roots under Zinc Stress. Silicon, 1-4. https://doi.org/10.1007/s12633-015-9376-6

Sousa, F. Q., Araújo, J. L., Silva, A. P., Pereira, F. H., Santos, R. V., \& Lima, G. S. (2012). Crescimento e respostas fisiológicas de espécies arbóreas em solo salinizado tratado com corretivos. Revista Brasileira de Engenharia Agrícola e Ambiental, 6(2), 173-181. https://doi.org/10.1590/S1415-43662012000200007

Souza, C. R., Soares, A. M., \& Regina, M. A. (2001). Trocas gasosas de mudas de videira, obtidas por dois porta-enxertos, submetidas à deficiência hídrica. Pesquisa Agropecuária Brasileira, 36(10), 1221-1230. https://doi.org/10.1590/S0100-204X2001001000002

Souza, R. P., Machado, E. C., Silveira, J. A. G., \& Ribeiro, R. V. (2011). Fotossíntese e acúmulo de solutos em feijoeiro caupi submetido à salinidade. Pesquisa Agropecuária Brasileira, 46(6), 586-592. https://doi.org/ 10.1590/S0100-204X2011000600003

Suárez, N. (2011). Effects of short-and long-term salinity on leaf water relations, gas exchange, and growth in Ipomoea pes-caprae. Flora - Morphology, Distribution, Functional Ecology of Plants, 206(3), 267-275. https://doi.org/10.1016/j.flora.2010.05.006

Tausz, M., Šircelj, H., \& Grill, D. (2004). The glutathione system as a stress marker in plant ecophysiology: is a stress-response concept valid? Journal of Experimental Botany, 55(404), 1955-1962. https://doi.org/ $10.1093 / \mathrm{jxb} / \mathrm{erh} 194$

Torres, E. C. M., Freire, J. L. O., Oliveira, J. L., Bandeira, L. B., Melo, D. A., \& Silva, A. L. (2014). Biometria de mudas de cajueiro anão irrigadas com águas salinas e uso de atenuadores do estresse salino. Nativa, 2(2), 71-78. https://doi.org/10.14583/2318-7670.v02n02a03

Van Kooten, O., \& Snel, J. F. H. (1990). The use of chlorophyll fluorescence nomenclature in plant stress physiology. Photosynthesis Research, 25(3), 147-150. https://doi.org/10.1007/BF00033156

Wang, Y., \& Wu, W. H. (2013). Potassium transport and signaling in higher plants. Annual Review of Plant Biology, 64(1), 451-476. https://doi.org/10.1146/annurev-arplant-050312-120153

Warren, C. R. (2008). Soil water deficits decrease the internal conductance to $\mathrm{CO}_{2}$ transfer but atmospheric water déficits do not. Journal of Experimental Botany, 59(2), 327-334. https://doi.org/10.1093/jxb/erm314

Zimmermann, G., Bäumlein, H., Mock, H. P., Himmelbach, A., \& Schweizer, P. (2006). The multigene family encoding germin-like proteins of barley. Regulation and function in basal host resistance. Plant Physiology, 142(1), 181-192. https://doi.org/10.1104/pp.106.083824

\begin{abstract}
Abbreviations
APX: Ascorbate peroxidase; ASC: Ascorbate; $C_{I}$ : Intercellular $\mathrm{CO}_{2}$ concentration; $E$ : Sweating rate; ETR: Apparent rate of transport and electrons; ETR/ $\mathrm{P}_{N}$ : Excess electrons for photosynthesis; $\mathrm{Fv} / \mathrm{Fm}$ : Maximus quantum efficiency of photosystem II; GSH: Glutathione reductase; $\mathrm{H}_{2} \mathrm{O}_{2}$ : Hydrogen peroxide; NBT: Nitroblue tetrazolium; NPQ: Non-photochemical quenching; $\mathrm{P}_{N}$ : $\mathrm{CO}_{2}$ assimilation rate; $\mathrm{P}_{N} / C_{I}$ : Maximum carboxylation efficiency; $\mathrm{P}_{N} / E$ : Efficiency of water use; POX: Phenol Peroxidase; PS: Photosystem; qP: Photochemical Quenching; ROS: Oxigen-reactive species; SOD: Superoxide dismutase; TBARS: Lipid peroxidation; TCA: Trichloroacetic acid; $\Delta \mathrm{F} / \mathrm{Fm}$ ': Quantum efficiency of photosystem II.
\end{abstract}

\title{
Copyrights
}

Copyright for this article is retained by the author(s), with first publication rights granted to the journal.

This is an open-access article distributed under the terms and conditions of the Creative Commons Attribution license (http://creativecommons.org/licenses/by/4.0/). 